\title{
Human activity in the surroundings of a former mill pond (Turznice, N Poland): implications for soil classification and environmental hazard assessment
}

\author{
Łukasz Mendyk ${ }^{1 *}$, Piotr Hulisz ${ }^{2}$, Marcin Świtoniak², Barbara Kalisz ${ }^{3}$, Waldemar Spychalski ${ }^{1}$ \\ ${ }^{1}$ Poznań University of Life Sciences, Faculty of Agronomy and Bioengineering, Department of Soil Science and Land Protection, Szydłowska \\ St. 50, 60-656 Poznań, Poland \\ ${ }^{2}$ Nicolaus Copernicus University in Toruń, Faculty of Earth Sciences and Spatial Management, Department of Soil Science and Landscape \\ Management, Lwowska St. 1, 87-100 Toruń, Poland \\ ${ }^{3}$ University of Warmia and Mazury in Olsztyn, Faculty of Environmental Management and Agriculture, Department of Soil Science and Land \\ Reclamation, Plac Łódzki 3, 10-727 Olsztyn, Poland \\ * Dr. Ł. Mendyk, lukasz.mendyk@up.poznan.pl, ORCID iD: https://orcid.org/0000-0002-7066-6014
}

Received: 01.09.2020

Accepted: 11.12.2020

Associated editor: J. Waroszewski

\section{Keywords}

Soil Classification Aggerosols Relocatic qualifier Heavy metals Pollution indices

\begin{abstract}
Growing human impact on the environment, including soil, is being reflected in the evolution of soil classification systems, which include adjustments to enable the proper and complex classification of anthropogenic soils. An example of human-changed landscapes is molinotopes, where soils and other landscape elements were altered due to the construction and operation of water mills. Four soil profiles were selected in the immediate surroundings of a former mill pond in Turznice village (the Grudziądz Basin, N Poland), where specific anthropogenic soils were formed. The aims of the study were: 1) to determine the systematic position of the studied soils in relation to their humanimpacted genesis, and 2) to assess the status of pollution by toxic metals including $\mathrm{Cd}, \mathrm{Cr}, \mathrm{Cu}, \mathrm{Ni}, \mathrm{Pb}$ and $\mathrm{Zn}$. Profiles 1, 2 and 3 were formed under undisputedly strong human influence, as revealed by their morphological features (i.e. artefacts, clear and abrupt horizon boundaries), basic properties (irregular changes of TOC not connected with natural soil-forming processes), selected heavy-metal contents and values of applied pollution index (enrichment with heavy metals in samples collected from horizons developed due to human activity). These profiles were classified as aggerosols (newly introduced soil type within the order of technogenic soils) according to PSC (2019) or Phaeozems (profiles 1 and 2) and Arenosol (profile 3). While the systematic position of these pedons according to PSC (2019) is a direct result of their anthropogenic genesis, only the Relocatic qualifier indicates such an influence according to WRB (IUSS, 2015). Profile 4, representing quasi-natural pedon in the vicinity of the former mill pond, was classified as arenosol according to PSC (2019) and as Phaeozem according to WRB (IUSS, 2015). In regards to both national and international regulations, the collected soil samples are considered to be unpolluted by the studied heavy metals. The obtained results expand our knowledge of the soil cover evolution induced with human activities around former mill ponds and could be useful in the complex assessment of landscape classification.
\end{abstract}

\section{Introduction}

While anthropogenic alteration of natural environments is happening on an unprecedented scale, earth scientists are still arguing about the term "Anthropocene", since it was suggested as the new epoch in 1960 and became popular in the 2000s (Crutzen, 2006; Brown et al., 2016; Waters et al., 2016; Laurance, 2019). One example of human-changed or even human-formed landscapes is molinotopes, or "landscapes of mill settlements" (Egelie, 1977; Podgórski, 2004). These landscapes are widely distributed across modern Europe as the peak of their development, estimated as hundreds of thousands of such facilities, dates to the beginning of the 19th century (Madry et al., 2015; Brown et al., 2018; Kaiser et al., 2018; Brykała and Podgórski, 2020). Most papers concerning environmental changes due to the construction and operation of water mills deal with hydrological and geomorphological alterations to the landscape (Podgórski, 2004; Bishop \& MuńozSalinas, 2013; Hupp et al., 2013; Madry et al., 2015). Despite the fact that mill pond sediments are used mostly for environmental reconstructions (e.g. Kittel et al., 2014; Royall and Kennedy, 2016; Fajer and Rzętała, 2017), in the last few years former mill ponds have been gaining interest among soil scientists (e.g. Jonczak 
and Florek, 2013; Jonczak, 2015; Mendyk et al., 2015; Mendyk et al., 2016a) but there is still a need to study human impact on the evolution of soil cover around former mill ponds.

The high importance of human impact on the environment, including soil (Howard and Daniels, 2017) is reflected in the evolution of soil classification systems, which includes adjustments to enable the proper and complex classification of anthropogenic soils (IUSS, 2015; Galbraith, 2018; Kabała et al., 2019). When dealing with such specific, strongly transformed or even humanmade soils, potential pollution should be taken into account, especially in health risk assessments (Charzyński et al., 2018). Such an approach is presented not only in the studies of urban soils (Beroigui et al., 2020) but also in agro-ecosystems (Ripin et al., 2014). Thus, the main aim of the study was to determine the systematic position of the studied soils according to the Polish Soil Classification (2019) and World Reference Base for Soil Resources (IUSS Working Group WRB, 2015) in respect to their humanimpacted genesis. Secondarily, selected heavy metal contents were determined, and pollution index was applied to assess the potential contamination of these specific anthropogenic soils.

\section{Materials and methods}

\subsection{Study area}

The study was carried out in the surroundings of the former Turznice mill pond basin. The mill and mill pond were located in the south-east of the Grudziądz Basin (Kot, 2015) on the edge of the fifth terrace of the Vistula River. The depression used for the mill pond was deepened and enclosed with a system of four dams constructed using local earth materials (Podgórski, 2004). The mill was built on the Turznica stream, which drains the edge of a till plain to the south (Fig. 1).

The history of the Turznice mill (Podgórski, 2004) begins in the middle of the 17th century. It operated as a gristmill (Brykała and Podgórski, 2020) with some interruptions until the mid-20th century, after which the dams surrounding the basin were destroyed and the materials used for their construction were utilised due to levelling the surface to the east of the basin.

According to the Köppen-Geiger climate classification, the region is located in a warm temperate, humid zone with warm summer (Kottek et al., 2006). The average annual air temperature is about $8^{\circ} \mathrm{C}$. The average annual precipitation is $505 \mathrm{~mm}$ (Wójcik and Marciniak, 1987, 1993).

The potential natural vegetation of the study area is ash-elm riparian forests and hornbeam forests, such as Ficario-Ulmetum and Tilio-Carpinetum, respectively (Matuszkiewicz, 2008). The present vegetation around the former mill pond is meadows, pastures and communities typical of arable lands with some belts of willow shrubs.

\subsection{Field and analytical work}

Four soil profiles were selected for the study. Profiles 1-3 represent soils formed under significant influence of human activities in the area, while profile 4 was chosen as an example of a relatively non-transformed soil from the former mill pond surroundings.

The morphology of the soil profiles was described in respect of the Polish Soil Classification (2019) and Guidelines for soil description (Jahn et al., 2006) and samples were collected from the soil horizons.

The following soil properties were determined in the collected samples: bulk density by the oven-dry method; solid particle density according to Marcinek and Spychalski (1987) for the needs of calculating total porosity; total porosity on the basis of bulk density and solid particle density; particle size distribution by the sieve method and the hydrometer method (using a Bouyoucos aerometric, modified by Cassagrande and Prószyński) using standard procedure recommended by the Soil Science Society of Poland (PSC 2019); and the names of the texture classes were

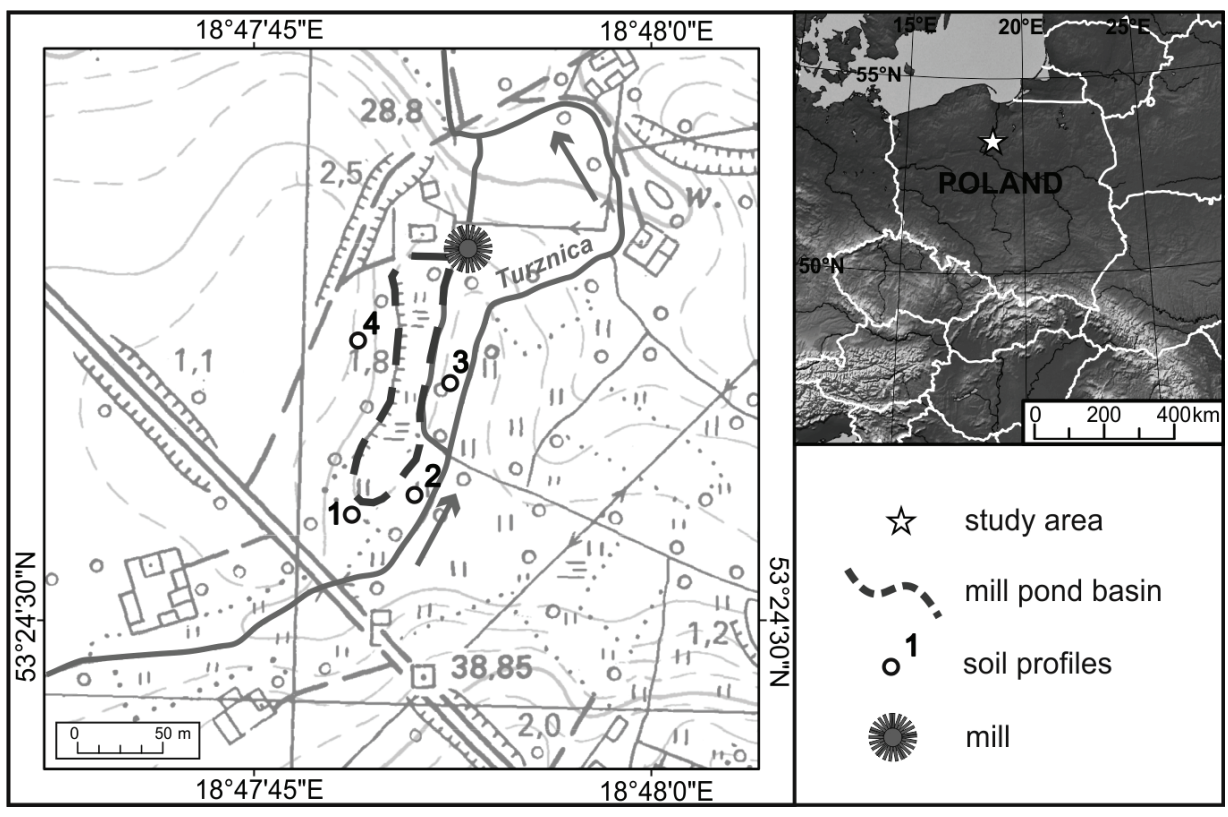

Fig. 1. Location of the study area and studied soil profiles 
given in line with the USDA (Soil Survey Division Staff, 1993). The total organic carbon (TOC) and total nitrogen (TN) content were measured using a Vario MaxCube CN Elementar analyser in steel cylinders (PSC 2019); pH at a soil-to-solution ratio of 1:2.5 using $1 \mathrm{M} \mathrm{KCl}$ and $\mathrm{H}_{2} \mathrm{O}$ as the suspension medium; and content of carbonates by the Scheibler volumetric method (PSC 2019). The total contents of selected metallic elements ( $\mathrm{Fe}, \mathrm{Cu}, \mathrm{Zn}, \mathrm{Pb}, \mathrm{Ni}, \mathrm{Cr}$, Cd) were determined using a Spectra AA 220 FS atomic absorption spectrometer (Varian) with background correction after acid digestion. Soil samples (1 g) were placed in a heating block and digested with $5 \mathrm{ml}$ of nitric acid (ultra-pure 65\%) and $1 \mathrm{ml}$ of perchloric acid (ultra-pure $70 \%$ ) at $130^{\circ} \mathrm{C}$ for $12 \mathrm{~h}$. After dilution to $50 \mathrm{ml}$, the samples were analysed. The soils were classified according to the sixth edition of the Polish Soil Classification (2019) and WRB classification system (IUSS Working Group WRB, 2015). The English equivalents for the soil taxa names in the Polish Soils Classification were provided after Kabała et al. (2019).

In order to comprehensively assess possible soil pollution degree (Kowalska et al., 2018) the Enrichment Factor index (EF) was calculated for each individual heavy metal $(\mathrm{Cu}, \mathrm{Zn}, \mathrm{Pb}, \mathrm{Ni}$, $\mathrm{Cr}, \mathrm{Cd}$ ) content in soil samples.

To identify the expected impact of anthropogenesis on the heavy metal concentrations in the soil, the content of heavy metals characterized by low variability of occurrence (LV) is used as a reference, both in the analyzed samples and in geochemical background. For this research iron content was used as the low variability of occurrence metal calculation (Sutherland 2000: Kowalska et al. 2018). EF is calculated using the following formula (Sutherland 2000):

$$
E F=\frac{\left[\frac{C n}{L V}\right] \text { sample }}{\left[\frac{C n}{L V}\right] \text { background }}
$$

Where $[\mathrm{Cn} / \mathrm{LV}]$ sample is a content of analysed heavy metal (Cn) in relation to low variability of occurrence metal content (LV) in the analysed sample and [Cn/LV] background is a background content value of analysed heavy metal in relation background content value of the low variability of occurrence metal content (Sutherland 2000). The geochemical background was calculated using iterative 2 $\sigma$-technique (Matschullat et al., 2000; Gałuszka and Migaszewski, 2011).

\section{Results}

\subsection{Soil morphology, selected physical and selected chemi- cal properties}

The soil under study differed in terms of presented morphology and determined properties (Table 1, Table 2, Fig. 2). Profile 1 had a thick, dark humus horizon $(80 \mathrm{~cm})$, with very few (less than $2 \%$ by volume) artefacts (bricks fragments), very few charcoals, granular structure and clear boundary to the Ccgg horizon. Oxymorphic colours were covering between $2 \%$ and 5\% in the Ccgg horizon, while the rest of soil material in this horizon, like the entire Cgg horizon had a reductimorphic colour indicating a medium deep gleyic properties (ground water table was present at $100 \mathrm{~cm}$ ). The texture was relatively homogeneous, from loamy fine sand $(0-95 \mathrm{~cm})$ to fine sand (> 95 $\mathrm{cm})$. Bulk density values increased from the top to the bottom of the soil profile, while total porosity decreased (Table 1). Total organic carbon (TOC) content dropped from over $16 \mathrm{~g} \cdot \mathrm{kg}^{-1}$ to $1 \mathrm{~g} \cdot \mathrm{kg}^{-1}$ from the surface to the lowest part of the soil profile. The soil $\mathrm{pH}$ changed irregularly from 7.4 to 7.7 in $\mathrm{H}_{2} \mathrm{O}$, the same as the carbonates content, which was about $20 \mathrm{~g} \cdot \mathrm{kg}^{-1}$ on the humus horizon and $2 \mathrm{~g} \mathrm{~kg}^{-1}$ (quantification threshold for the Scheibler volumetric method) in the $\mathrm{C}$ horizon (Table 2).

The morphology of profile 2 was much more complex. In total, six horizons and subhorizons were designated (Fig. 2). Except for the surface humic horizons divided into two subhorizons (Ad and A [0-10 and 10-26 cm]), all the boundaries were clear or abrupt. While granular and subangular structure was recognised in the upper part of the profile $(0-43 \mathrm{~cm})$, the soil material in the bottom part was not aggregated (massive structure in Cgg and G2 horizons and single grain in G1 horizon). The texture was finer - from fine sandy loam in the upper $43 \mathrm{~cm}$ to loamy fine sand down to the depth of $150 \mathrm{~cm}$ (except for the G1 horizon, with the texture of fine sand). Similarly to profile 1, the lowest value of bulk density and highest porosity was determined for the surface horizon, but then it varied down to the bottom with no clear pattern and soil material was much more loose in profile 2 (Table 1). Fragments of bones and charcoals were found in the Ad horizon, while very few (less than $2 \%$ by volume) artefacts (bricks fragments and ceramic remains) or charcoals were present in the A horizon, and then a very few bone fragments were discovered in the bottom horizon (G2). Oxymorphic colours covering less than $5 \%$ in form of precipitations around the root channels were distinguished in the A horizon $(10-26 \mathrm{~cm})$, than $25 \%$ to $35 \%$ of the Bc horizon $(26-43 \mathrm{~cm})$ was covered with dark reddish brown and brown mottles. All the soil material starting at $43 \mathrm{~cm}$ to the bottom of the soil profile was characterized with reductimorphic colours. While few reddish mottles formed due to the Fe precipitations around the root channels were spotted in the Cgg horizon, no oxymorphic features were distinguished in the G1 and G2 horizons. For the presence of these morphologic features presence, gleyic properties were recognized (ground water table was present at $80 \mathrm{~cm}$ ). Content of TOC reached the highest values in the horizons $\mathrm{Ad}$ $(0-10 \mathrm{~cm})$ and G2 (61-150 cm): about 37 and $24 \mathrm{~g} \cdot \mathrm{kg}^{-1}$, respectively. Profile 2 was characterised by slightly more alkaline reaction than was profile 1. Soil $\mathrm{pH}\left(\mathrm{H}_{2} \mathrm{O}\right)$ varied from 7.5 in horizons richest in organic matter to 8.3 in the $\mathrm{Bc}(26-43 \mathrm{~cm})$ horizon, and

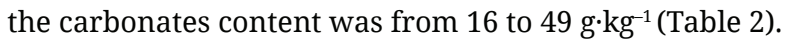

As many as eight subhorizons were recognised in profile 3. The upper five had clear or abrupt boundaries (Table 1, Fig. 2). The boundary distinctness and topography were not determined for the bottom soil horizons as they were sampled using a hand auger. Very few artefacts (less than $2 \%$ by volume) and bone fragments were observed only in the $\mathrm{Cc} 2$ horizon, starting from $30 \mathrm{~cm}$ at the left side of the profile and from $50 \mathrm{~cm}$ at the right side, and down to 80 and $85 \mathrm{~cm}$, respectively. Common mussel shells were present at the depth of about 100 to $120 \mathrm{~cm}$ (Cgg horizon). More than $5 \%$ of the $\mathrm{Cc} 3$ horizon surface was covered with oxymorphic 


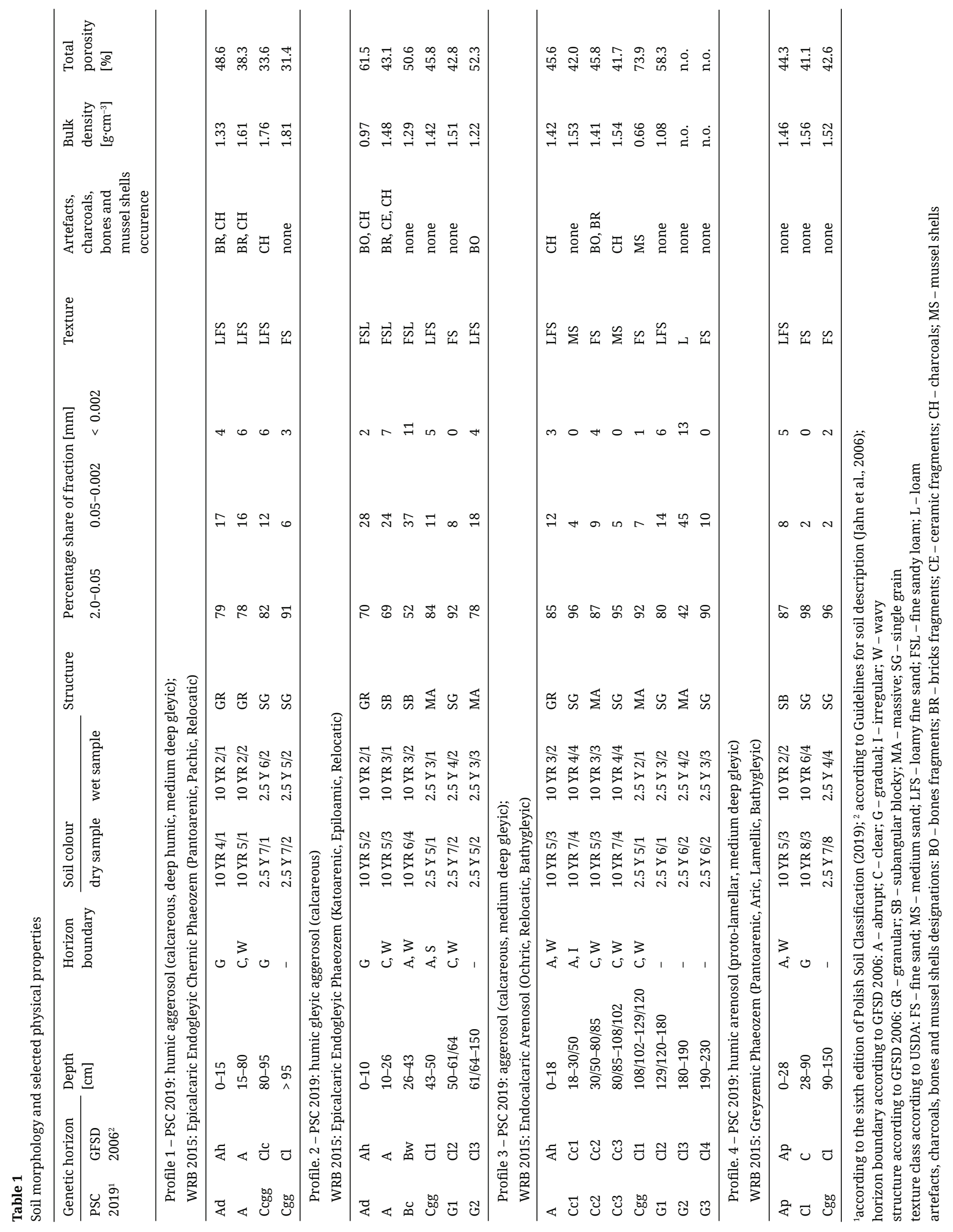


Table 2

Selected soil chemical properties
${ }^{1}$ according to the sixth edition of Polish Soil Classification (2019); 2according to Guidelines for soil description (Jahn et al., 2006);

\begin{tabular}{|c|c|c|c|c|c|c|c|c|}
\hline \multicolumn{2}{|c|}{ Genetic horizon } & \multirow[t]{2}{*}{ Depth [cm] } & TOC & $\mathrm{TN}$ & \multirow[t]{2}{*}{$\mathrm{C}: \mathrm{N}$} & \multirow[t]{2}{*}{$\mathrm{pH} \mathrm{H}_{2} \mathrm{O}$} & \multirow[t]{2}{*}{$\mathrm{pH} \mathrm{KCl}$} & \multirow{2}{*}{$\begin{array}{l}\mathrm{CaCO}_{3} \\
{\left[\mathrm{~g} \cdot \mathrm{kg}^{-1}\right]}\end{array}$} \\
\hline PSC $2019^{1}$ & GFSD $2006^{2}$ & & $\mathrm{~g} \cdot \mathrm{kg}^{-1}$ & & & & & \\
\hline \multicolumn{9}{|c|}{$\begin{array}{l}\text { Profile } 1 \text { - PSC 2019: humic aggerosol (calcareous, deep humic, medium deep gleyic); } \\
\text { WRB 2015: Epicalcaric Endogleyic Chernic Phaeozem (Pantoarenic, Pachic, Relocatic) }\end{array}$} \\
\hline Ad & $\mathrm{Ah}$ & 0-15 & 16.04 & 1.48 & 10 & 7.4 & 7.2 & 18 \\
\hline A & A & $15-80$ & 10.30 & 0.90 & 11 & 7.6 & 7.2 & 22 \\
\hline Ccgg & Clc & 80-95 & 1.02 & 0.10 & 10 & 7.7 & 6.9 & 2 \\
\hline Cgg & $\mathrm{Cl}$ & $>95$ & n.o. & n.o. & n.o. & 7.7 & 7.0 & 2 \\
\hline
\end{tabular}

Profile 2 - PSC 2019: humic gleyic aggerosol (calcareous)

WRB 2015: Epicalcaric Endogleyic Greyzemic Phaeozem (Katoarenic, Epiloamic, Relocatic)

\begin{tabular}{lllllllll}
\hline $\mathrm{Ad}$ & $\mathrm{Ah}$ & $0-10$ & 37.00 & 3.06 & 12 & 7.5 & 7.2 & 25 \\
$\mathrm{~A}$ & $\mathrm{~A}$ & $10-26$ & 15.04 & 1.27 & 11 & 8.0 & 7.3 & 37 \\
$\mathrm{Bc}$ & $\mathrm{Bw}$ & $26-43$ & 10.00 & 0.85 & 11 & 8.3 & 7.6 & 42 \\
$\mathrm{Cgg}$ & $\mathrm{Cl} 1$ & $43-50$ & 9.23 & 0.81 & 11 & 8.1 & 7.5 & 26 \\
$\mathrm{G} 1$ & $\mathrm{Cl} 2$ & $50-61 / 64$ & 4.08 & 0.39 & 10 & 8.2 & 7.9 & 16 \\
$\mathrm{G} 2$ & $\mathrm{Cl} 3$ & $61 / 64-150$ & 24.80 & 1.41 & 17 & 7.5 & 7.3 & 49 \\
\hline
\end{tabular}

Profile 3 - PSC 2019: aggerosol (calcareous, medium deep gleyic);

WRB 2015: Endocalcaric Arenosol (Ochric, Relocatic, Bathygleyic)

\begin{tabular}{lllllllll}
\hline A & Ah & $0-18$ & 12.40 & 1.16 & 10 & 7.5 & 7.3 & 31 \\
Cc1 & Cc1 & $18-30 / 50$ & n.o. & n.o. & n.o. & 8.0 & 8.1 & 15 \\
Cc2 & Cc2 & $30 / 50-80 / 85$ & 13.09 & 0.94 & 13 & 7.8 & 7.6 & 22 \\
Cc3 & Cc3 & $80 / 85-108 / 102$ & 4.22 & 0.24 & 17 & 8.0 & 7.9 & 15 \\
Cgg & Cl1 & $108 / 102-129 / 120$ & 36.30 & 2.55 & 14 & 7.1 & 7.1 & 30 \\
G1 & Cl2 & $129 / 120-180$ & 16.60 & 1.33 & 12 & 7.4 & 7.4 & 59 \\
G2 & Cl3 & $180-190$ & 30.60 & 1.87 & 16 & 7.4 & 6.9 & 46 \\
G3 & Cl4 & $190-230$ & 3.25 & 0.45 & 7 & 7.5 & 7.0 & 79
\end{tabular}

Profile 4- PSC 2019: humic arenosol (proto-lamellar, medium deep gleyic)

WRB 2015: Greyzemic Phaeozem (Pantoarenic, Aric, Lamellic, Bathygleyic)

\begin{tabular}{lllllllll}
\hline A & A & $0-28$ & 7.69 & 0.69 & 11 & 8 & 7.4 & 6 \\
$\mathrm{Cl}$ & $\mathrm{C}$ & $28-90$ & n.o. & n.o. & n.o. & 8.2 & 7.1 & 3 \\
$\mathrm{Cgg}$ & $\mathrm{Cl}$ & $90-150$ & n.o. & n.o. & n.o. & 8.2 & 7.1 & 1 \\
\hline
\end{tabular}

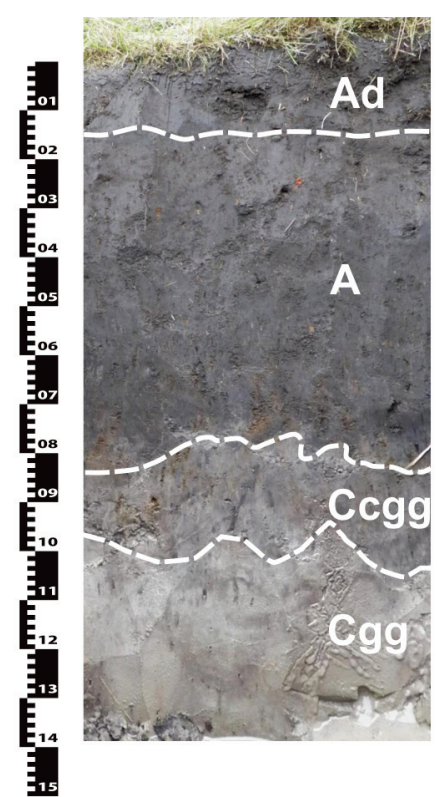

PROFILE 1

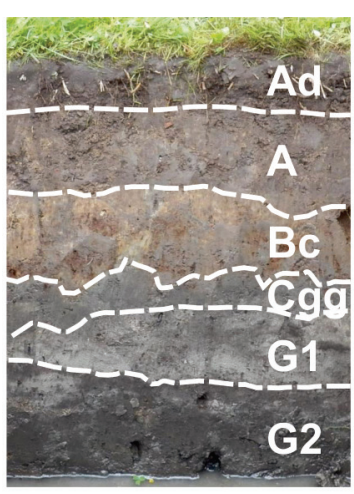

PROFILE 2

Fig. 2. Soil morphology. Symbols of horizons according to Polish Soil Classification (2019)

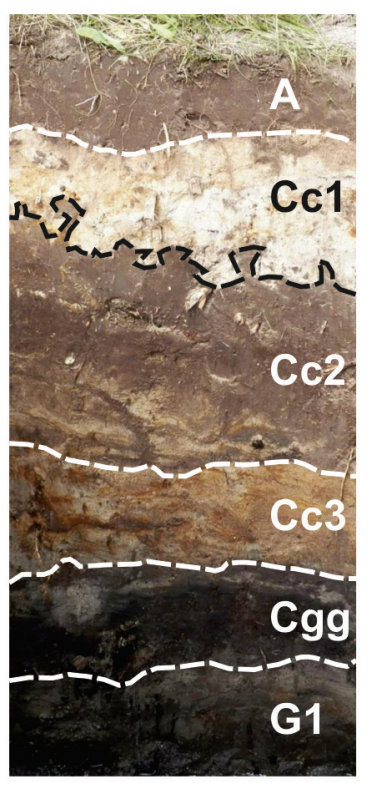

PROFILE 3

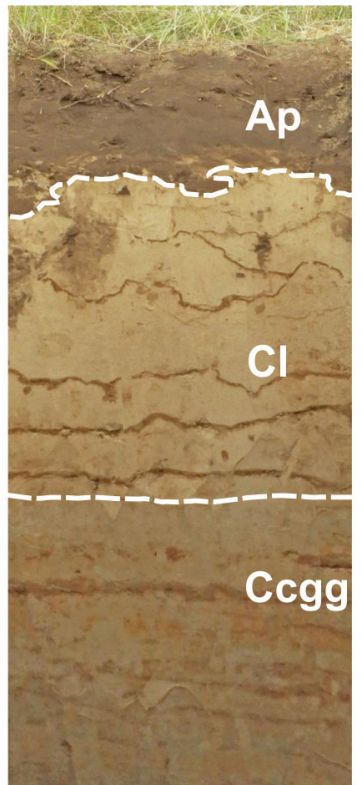

PROFILE 4 
colours and starting with Cgg horizon down the $190 \mathrm{~cm}$ colours related to reducing conditions were distinguished. That is why medium deep gleyic properties were recognized in this soil profile (ground water table was present below the depth of $150 \mathrm{~cm}$ ). The texture of soil material sampled from this profile was the most diverse: from medium sands to loam. Soil aggregation was noticed only in the A horizon with granular structure, then single grain and massive structure were observed down to the bottom of the soil profile. Values of bulk density and total porosity varied in a very irregular way - the most loose and porous horizon was Cgg, while the firmest was immediately overlying Cc3 (Table 1). TOC content was about $4-13 \mathrm{~g} \cdot \mathrm{kg}^{-1}$ in the upper soil horizons (to $100 \mathrm{~cm})$ and $3-36 \mathrm{~g} \cdot \mathrm{kg}^{-1}$ in the bottom part (100-230 cm). Soil pH determined in $\mathrm{H}_{2} \mathrm{O}$ solution was from 6.9 to 8.1. Carbonates content generally increased from the surface to the bottom, with a minimum content of $15 \mathrm{~g} \cdot \mathrm{kg}^{-1}$ and a maximum of 79 .

The last profile consisted of three horizons with abrupt boundary from A to $\mathrm{Cl}$ horizon and gradual boundary from $\mathrm{Cl}$ to Cgg horizon. Weak subangular blocky structure was observed in the surface horizon, but single grain structure in subsurface horizons. Texture was loamy fine sand in the humus horizon and fine sand in parent material. Bulk density values and total porosity were very similar in all designated horizons (Table 1).
No artefacts, bone fragments or charcoals were present in soil material sampled from profile 4 . More than 5\% of the Cgg horizon surface was covered with oxymorphic mottles indicating medium deep gleyic properties. TOC content was about $7.7 \mathrm{~g} \cdot \mathrm{kg}^{-1}$ in the humus horizon. The $\mathrm{pH}$ dropped from 7.4 in the A horizon to 7.1 in the $\mathrm{Cl}$ and $\mathrm{Cgg}$ horizons. Carbonates content was very low when compared to previously presented profiles: $1-6 \mathrm{~g} \cdot \mathrm{kg}^{-1}$.

\subsection{Selected metallic element contents and values of pollution indices}

Of all the metallic element contents determined for the study, iron was highest. Iron content varied from about $2 \mathrm{~g} \cdot \mathrm{kg}^{-1}$ (profile 2, G1 horizon) to almost $20 \mathrm{~g} \cdot \mathrm{kg}^{-1}$ (profile 3 , Bc horizon). When taking into account other elements that could be named together as potential toxic elements (PTEs) Zn had the highest content (5.96-65.2 $\left.\mathrm{mg} \cdot \mathrm{kg}^{-1}\right)$. The next was $\mathrm{Cr}\left(3.01-13.7 \mathrm{mg} \cdot \mathrm{kg}^{-1}\right)$, then $\mathrm{Pb}\left(0.44-12.5 \mathrm{mg} \cdot \mathrm{kg}^{-1}\right)$, Ni (0.70-11.2 $\left.\mathrm{mg} \cdot \mathrm{kg}^{-1}\right), \mathrm{Cu}(0.83-6.98$ $\left.\mathrm{mg} \cdot \mathrm{kg}^{-1}\right)$ and $\mathrm{Cd}\left(0.01-0.09 \mathrm{mg} \cdot \mathrm{kg}^{-1}\right)$. Considerable variability in PTE content was observed both between the studied soil profiles and in terms of vertical differentiation of each individual soil profile. Higher contents of PTEs were observed in soils considered to be more influenced by human activity (Table 3).
Table 3

Content of selected metals in the studied soils

${ }^{1}$ according to the sixth edition of Polish Soil Classification (2019); ${ }^{2}$ according to Guidelines for soil description (Jahn et al., 2006)

\begin{tabular}{|c|c|c|c|c|c|c|c|c|c|}
\hline \multicolumn{2}{|c|}{ Genetic horizon } & \multirow[t]{2}{*}{ Depth [cm] } & $\mathrm{Fe}$ & $\mathrm{Cu}$ & $\mathrm{Zn}$ & $\mathrm{Pb}$ & $\mathrm{Ni}$ & $\mathrm{Cr}$ & $\mathrm{Cd}$ \\
\hline PSC $2019^{1}$ & GFSD $2006^{2}$ & & \multicolumn{7}{|c|}{$\mathrm{mg} \cdot \mathrm{kg}^{-1}$} \\
\hline \multicolumn{10}{|c|}{$\begin{array}{l}\text { Profile } 1 \text { - PSC 2019: humic aggerosol (calcareous, deep humic, medium deep gleyic); } \\
\text { WRB 2015: Epicalcaric Endogleyic Chernic Phaeozem (Pantoarenic, Pachic, Relocatic) }\end{array}$} \\
\hline Ad & $\mathrm{Ah}$ & 0-15 & 7572 & 6.59 & 41.4 & 10.7 & 3.23 & 7.87 & 0.08 \\
\hline A & A & $15-80$ & 8455 & 6.98 & 35.8 & 7.16 & 4.79 & 9.07 & 0.05 \\
\hline Ccgg & $\mathrm{Clc}$ & 80-95 & 3317 & 1.54 & 7.99 & 2.33 & 1.57 & 4.45 & 0.01 \\
\hline Cgg & $\mathrm{Cl}$ & $>95$ & 2826 & 1.20 & 7.17 & 2.10 & 1.97 & 4.34 & 0.02 \\
\hline
\end{tabular}

Profile 2 - PSC 2019: humic gleyic aggerosol (calcareous);

WRB 2015: Epicalcaric Endogleyic Phaeozem (Katoarenic, Epiloamic, Relocatic)

\begin{tabular}{llllllllll}
\hline $\mathrm{Ad}$ & $\mathrm{Ah}$ & $0-10$ & 13200 & 6.89 & 32.5 & 12.5 & 6.49 & 13.7 & 0.09 \\
$\mathrm{~A}$ & $\mathrm{~A}$ & $10-26$ & 13920 & 6.04 & 31.2 & 12.3 & 5.54 & 10.6 & 0.01 \\
$\mathrm{Bc}$ & $\mathrm{Bw}$ & $26-43$ & 19700 & 5.55 & 25.0 & 8.98 & 8.63 & 12.2 & 0.01 \\
$\mathrm{Cgg}$ & $\mathrm{Cl} 1$ & $43-50$ & 9454 & 2.85 & 14.3 & 6.86 & 4.20 & 9.20 & 0.01 \\
$\mathrm{G} 1$ & $\mathrm{Cl} 2$ & $50-61 / 64$ & 2105 & 1.07 & 5.96 & 1.83 & 0.83 & 2.37 & 0.03 \\
$\mathrm{G} 2$ & $\mathrm{Cl} 3$ & $61 / 64-150$ & 10380 & 3.57 & 18.8 & 3.76 & 5.42 & 8.65 & 0.01 \\
\hline
\end{tabular}

Profile 3 - PSC 2019: aggerosol (calcareous, medium deep gleyic);

WRB 2015: Endocalcaric Arenosol (Ochric, Relocatic, Bathygleyic)

\begin{tabular}{llllllllll}
\hline A & Ah & $0-18$ & 8464 & 3.50 & 18.4 & 4.30 & 3.60 & 7.26 & 0.07 \\
Cc1 & Cc1 & $18-30 / 50$ & 4124 & 0.94 & 5.17 & 1.01 & 4.94 & 4.78 & 0.02 \\
Cc2 & Cc2 & $30 / 50-80 / 85$ & 5384 & 2.58 & 13.3 & 2.90 & 3.69 & 4.93 & 0.02 \\
Cc3 & Cc3 & $80 / 85-108 / 102$ & 4146 & 0.90 & 11.2 & 1.65 & 1.00 & 2.74 & 0.02 \\
Cgg & Cl1 & $108 / 102-129 / 120$ & 3325 & 1.82 & 15.9 & 0.72 & 1.35 & 2.36 & 0.02 \\
G1 & Cl2 & $129 / 120-180$ & 6238 & 2.40 & 18.0 & 1.81 & 3.28 & 4.56 & 0.02 \\
G2 & Cl3 & $180-190$ & 14670 & 8.43 & 65.2 & 9.58 & 11.2 & 10.5 & 0.02 \\
G3 & Cl4 & $190-230$ & 3391 & 1.30 & 13.9 & 0.44 & 1.44 & 3.01 & 0.01 \\
\hline
\end{tabular}

Profile. 4 - PSC 2019: humic arenosol (proto-lamellar, medium deep gleyic)

WRB 2015: Greyzemic Phaeozem (Pantoarenic, Aric, Lamellic, Bathygleyic)

\begin{tabular}{llllllllll}
\hline $\mathrm{A}$ & $\mathrm{A}$ & $0-28$ & 5572 & 5.63 & 30.5 & 8.95 & 2.68 & 6.97 & 0.06 \\
$\mathrm{Cl}$ & $\mathrm{C}$ & $28-90$ & 3663 & 0.83 & 6.22 & 1.25 & 0.70 & 6.21 & 0.01 \\
$\mathrm{Cgg}$ & $\mathrm{Cl}$ & $90-150$ & 4626 & 1.87 & 6.76 & 1.10 & 1.87 & 6.62 & 0.02 \\
\hline
\end{tabular}


Table 4

Values of the enrichment factor (EF) calculated for selected heavy metals

\begin{tabular}{|c|c|c|c|c|c|c|c|c|}
\hline \multicolumn{2}{|c|}{ Genetic horizon } & \multirow[t]{2}{*}{ Depth [cm] } & \multirow[t]{2}{*}{$\mathrm{Cu}$} & \multirow[t]{2}{*}{$\mathrm{Zn}$} & \multirow[t]{2}{*}{$\mathrm{Pb}$} & \multirow[t]{2}{*}{$\mathrm{Ni}$} & \multirow[t]{2}{*}{$\mathrm{Cr}$} & \multirow[t]{2}{*}{$\mathrm{Cd}$} \\
\hline PSC $2019^{1}$ & GFSD $2006^{2}$ & & & & & & & \\
\hline \multicolumn{9}{|c|}{$\begin{array}{l}\text { Profile } 1 \text { - PSC 2019: humic aggerosol (calcareous, deep humic, medium deep gleyic); } \\
\text { WRB 2015: Epicalcaric Endogleyic Chernic Phaeozem (Pantoarenic, Pachic, Relocatic) }\end{array}$} \\
\hline Ad & $\mathrm{Ah}$ & $0-15$ & 1.47 & 1.77 & 1.57 & 0.75 & 0.92 & 3.73 \\
\hline A & A & $15-80$ & 1.40 & 1.37 & 0.94 & 0.99 & 0.95 & 2.24 \\
\hline Ccgg & $\mathrm{Clc}$ & 80-95 & 0.78 & 0.78 & 0.78 & 0.83 & 1.18 & 1.41 \\
\hline Cgg & $\mathrm{Cl}$ & $>95$ & 0.72 & 0.82 & 0.83 & 1.22 & 1.36 & 2.90 \\
\hline
\end{tabular}

Profile 2 - PSC 2019: humic gleyic aggerosol (calcareous);

WRB 2015: Epicalcaric Endogleyic Phaeozem (Katoarenic, Epiloamic, Relocatic)

\begin{tabular}{lllllllll}
\hline $\mathrm{Ad}$ & $\mathrm{Ah}$ & $0-10$ & 0.88 & 0.80 & 1.05 & 0.86 & 0.92 & 2.41 \\
$\mathrm{~A}$ & $\mathrm{~A}$ & $10-26$ & 0.73 & 0.72 & 0.98 & 0.70 & 0.67 & 0.17 \\
$\mathrm{Bc}$ & $\mathrm{Bw}$ & $26-43$ & 0.48 & 0.41 & 0.51 & 0.77 & 0.55 & 0.12 \\
$\mathrm{Cgg}$ & $\mathrm{Cl} 1$ & $43-50$ & 0.51 & 0.49 & 0.81 & 0.78 & 0.86 & 0.50 \\
$\mathrm{G} 1$ & $\mathrm{Cl} 2$ & $50-61 / 64$ & 0.86 & 0.92 & 0.97 & 0.70 & 0.99 & 5.00 \\
$\mathrm{G} 2$ & $\mathrm{Cl} 3$ & $61 / 64-150$ & 0.58 & 0.59 & 0.40 & 0.92 & 0.74 & 0.45
\end{tabular}

Profile 3 - PSC 2019: aggerosol (calcareous, medium deep gleyic); WRB 2015: Endocalcaric Arenosol (Ochric, Relocatic, Bathygleyic)

\begin{tabular}{lllllllll}
\hline $\mathrm{A}$ & $\mathrm{Ah}$ & $0-18$ & 0.70 & 0.70 & 0.56 & 0.75 & 0.76 & 2.92 \\
$\mathrm{Cc} 1$ & $\mathrm{Cc} 1$ & $18-30 / 50$ & 0.51 & 0.54 & 0.36 & 2.78 & 1.35 & 2.25 \\
$\mathrm{Cc} 2$ & $\mathrm{Cc} 2$ & $30 / 50-80 / 85$ & 0.82 & 0.80 & 0.60 & 1.21 & 0.81 & 1.32 \\
$\mathrm{Cc} 3$ & $\mathrm{Cc} 3$ & $80 / 85-108 / 102$ & 0.37 & 0.87 & 0.44 & 0.42 & 0.58 & 1.69 \\
$\mathrm{Cgg}$ & $\mathrm{Cl} 1$ & $108 / 102-129 / 120$ & 0.93 & 1.54 & 0.24 & 0.71 & 0.63 & 2.49 \\
$\mathrm{G} 1$ & $\mathrm{Cl} 2$ & $129 / 120-180$ & 0.65 & 0.93 & 0.32 & 0.92 & 0.65 & 1.33 \\
$\mathrm{G} 2$ & $\mathrm{Cl} 3$ & $180-190$ & 0.97 & 1.44 & 0.73 & 1.34 & 0.63 & 0.41 \\
$\mathrm{G} 3$ & $\mathrm{Cl} 4$ & $190-230$ & 0.65 & 1.32 & 0.14 & 0.74 & 0.78 & 0.69 \\
\hline
\end{tabular}

Profile 4 - PSC 2019: humic arenosol (proto-lamellar, medium deep gleyic) WRB 2015: Greyzemic Phaeozem (Pantoarenic, Aric, Lamellic, Bathygleyic)

${ }^{1}$ according to the sixth edition of Polish Soil Classification (2019);

${ }^{2}$ according to Guidelines for soil description (Jahn et al., 2006);

\begin{tabular}{lllllllll}
\hline $\mathrm{A}$ & $\mathrm{Ap}$ & $0-28$ & 1.71 & 1.77 & 1.79 & 0.84 & 1.10 & 3.79 \\
$\mathrm{Cl}$ & $\mathrm{C}$ & $28-90$ & 0.39 & 0.55 & 0.38 & 0.34 & 1.50 & 0.64 \\
$\mathrm{Cgg}$ & $\mathrm{Cl}$ & $90-150$ & 0.68 & 0.47 & 0.27 & 0.71 & 1.26 & 1.27 \\
\hline
\end{tabular}

As shown in Table 4, the Enrichment Factor (EF) values are mostly below 1.5 (108 of 126 total calculations) which may suggest natural content of the studied elements. Values higher than 1.5, indicating possible impact of anthropogenic activity on heavy metal contents (Elias and Gbadegesin, 2011; Kowalska et al., 2018) were determined for 18 samples in total. Only for 10 cases did the values exceed 2.0, which can be interpreted as moderate enrichment, while the remainder were characterised by deficiency or minimal enrichment (Sutherland, 2000).

\section{Discussion}

\subsection{Soil genesis and classification}

Profiles 1, 2 and 3 were formed under undisputedly strong human influence. The morphology of the soil described in profile 1 indicates its formation as a result of the gradual adding of materials dredged from the mill pond basin during the mill's operation. This was common practice in order to maintain the capacity of mill ponds, as they were constantly being filled with sediments (Podgórski, 2004). The evidence of such genesis is the very thick humic horizon with the presence of few but regularly distributed artefacts (bricks fragments), and the clear, wavy boundary to the $\mathrm{C}$ horizon. Similar humus horizons of that thickness in agriculturally used young glacial landscapes are often described as having developed from colluvic materials, although to be recognised as such they must demonstrate more obvious stratification and are located in places indicating slope deposits accumulation (e.g. Świtoniak, 2014, 2015; Mendyk et al., 2016b; Kaiser et al., 2020). These earthen materials fit the criteria for thick heap material (PSC, 2019; Kabała et al., 2019) as it was removed from the pond intentionally, but not for agricultural purposes (e.g. as mineral fertiliser) as in Culturozems according to PSC (2019) or Anthrosols (or other soils with the Terric qualifier) according to WRB (IUSS, 2015) in case of this location. In fact, the morphological features are very similar to Anthrosols - especially these located within urban areas (e.g. Krupski et al., 2017). When discussing the systematic position of this pedon according to WRB (IUSS, 2015), the Relocatic qualifier (placed as the last of the supplementary qualifiers, as it is not listed with the Phaeozem) is the one that informs us about a human influence in soil formation. In fact the Terric qualifier, being used when a terric horizon is present, would better correspond with the gen- 
esis of this material (dredged bottom sediments). However, as we distinguished two humus subhorizons (mainly based on the abundance of roots; Table 1), it does not meet criterion No. 3 for Terric (i.e. "Does not show stratification”; IUSS, 2015). Thus, Profile 1 has been classified as a humic aggerosol (calcareous, deep humic, medium deep gleyic) according to PSC (2019) or as the Epicalcaric Endogleyic Chernic Phaeozem (Pantoarenic, Pachic, Relocatic) according to WRB (IUSS, 2015).

Profiles 2 and 3 were located at the levelled surface associated with the mill (Fig. 1). They were both developed partially from deposits dredged out of the mill pond basin (as the top part of profile 1) and from materials previously used to form the former dams. The morphology of both profiles manifests the direct impact of human activities (Figure 2). Horizon boundaries were mostly clear or abrupt, with wavy topography (Table 1): in addition, the G1 horizon in profile 2 and top parts of all subhorizons from Cc1 to Cg1 were strongly mixed. These features clearly indicate the soil material having been reworked with some tools (e.g. Krupski et al., 2017). Artefacts distributed at different depths also confirm the anthropogenic nature of these pedons. These features being a results of soil material relocating and make them similar to urban soils (Hulisz et al. 2018). Stronger stratification of these profiles is common for soil formed from dredged materials (Hulisz et al., 2015) by also assimilates them to Anthrosols developed within alluvial plains (Charzyński et al., 2018) or to soils formed on the surface of the fortifications (Jankowski et al. 2013, Pardela et al. 2020) . Basis on the presence of mussel shells in the G1 horizon (profile 2) and the $\mathrm{C}$ horizon (profile 3) we assume these were horizons developed from materials dredged from the basin while preparing the depression before constructing the mill pond (Podgórski, 2004). In both profiles these post-dam soil materials, most probably mixed to some extent with bottom sediments dredged from the pond, were $\geq 50 \mathrm{~cm}$ thick, allowing us to classify them as thick heap material, again (PSC, 2019). Both profiles were developed mainly from relocated material fulfilling the criteria for thick heap material (PSC, 2019; Kabała et al., 2019) without any doubts. While profile 2 was classified as Phaeozem due to the presence of a mollic horizon and profile 3 as Arenosol due to its sandy texture, the Relocatic was a supplementary qualifier used to express human influence according to WRB (IUSS, 2015), as for profile 1. Due to above described features, materials and diagnostic horizons, they were classified as humic gleyic aggerosol (calcareous) and aggerosols (calcareous medium-deep glyeic) according to PSC (2019) or as Epicalcaric Endogleyic Phaeozem (Katoarenic, Epiloamic, Relocatic) and Endocalcaric Arenosol (Ochric, Relocatic, Bathygleyic) according to WRB (IUSS, 2015).

Profile 4, classified as humic arenosol (proto-lamellar, medium deep gleyic) according to PSC (2019) and as Greyzemic Phaeozem (Pantoarenic, Aric, Lamellic, Bathygleyic) according to WRB (IUSS, 2015), is an example of a quasi-natural pedon in the vicinity of a former mill pond. It was developed from terrace sand, which is the main parent material for undisturbed soils occurring in the close surroundings of the study site. The texture of these sands (Table 1) strongly corresponds with bottom parts of the soil profiles located within the former mill pond, which are assumed as natural deposits relining the deposits accumu- lated in the pond while the mill was in operation (Mendyk et al., 2016a). The morphology of this pedon nevertheless shows some anthropogenic impact. The abrupt boundary of the relatively deep humus horizon is the obvious result of ploughing (e.g. Łabaz and Kabała, 2016). While the sandy texture in the whole described profile was crucial to classify this pedon as arenosol according to PSC (2019), deepening of the humus horizon due to ploughing resulted in the criteria for mollic horizon being fulfilled, which resulted in classification as Phaeozem according to WRB (IUSS, 2015). Moreover, taking into consideration the relatively high organic carbon and carbonates content, enrichment of the original surface with dredged materials cannot be excluded (Table 2).

Changes in the Polish Soil Classification follow the growing interest in human-altered and human-transported soils, as their extent is still underestimated and only a few of them could be described and classified adequately (Galbraith, 2018). Beside many other landscapes where such pedons exist, this newly introduced classification unit is crucial for the complex evaluation of the evolution and richness of soil cover within molinotopes. On the other hand, some sort of expert knowledge, i.e. detailed recognition of the historical context of these landscapes, seems to be the key to the proper identification of the human influence on these soils.

\subsection{Assessment of soil pollution degree}

Potential toxic element content ( $\mathrm{Cu}, \mathrm{Zn}, \mathrm{Pb}, \mathrm{Ni}, \mathrm{Cr}, \mathrm{Cd}$ ) was several times lower than that observed in soil samples collected from soil developed within the mill pond basin (Mendyk et al., 2016a), except for chromium, whose content was not analysed in the mentioned study. Studied soils are characterized which much lower content of heavy metals comparing to the floodplain soils of the Grudziądz Basin (Kobierski, 2015). The content of the above mentioned elements does not demonstrate any exceeding of the permissible threshold values included in Regulations of Minister of Environment (Regulation Me, 2016), neither for the depth of 0-25 cm below ground level, nor for $>25 \mathrm{~cm}$. In fact, the highest obtained results were in general a few times lower than the threshold values (Table 3). Furthermore, no exceeding of thresholds was noticed when comparing to the even more restrictive values of the Finnish Ministry of Environment (Ministry of the Environment, Finland, 2007), which represent a good approximation of the mean values of different national systems in Europe (Carlon et al., 2007; Tóth et al., 2016) and have been used in an international context for agricultural soils (UNEP, 2013).

The relatively high EF values calculated for profiles 1 and 4 surface horizons ( $\mathrm{Cu}, \mathrm{Zn}$ and $\mathrm{Pb}$ ) could be connected with these horizons being enriched with material dredged from the mill pond, as was stated earlier. The highest values, which could demonstrate moderate enrichment (EF 2.0-5.0) as well as being a result of anthropogenic activities (EF > 1.5), were calculated for cadmium (Table 4). As content of this element was very low and did not vary much (Table 3), the mentioned EF values were most probably an effect of the rather low content of iron used as the LV element for calculating this index. On 
the basis of EF values, the studied soil profiles could be divided into two groups. In profiles 1 and 4 much higher values were noticed for A horizons, except these calculated for $\mathrm{Cr}$ and $\mathrm{Cd}$. On the other hand, in profiles 3 and 4 a high variability of pollution indices values was observed. In general the high values were marked for horizons with high content of organic carbon (Table 2 and 4). Higher values of EF calculated for the $\mathrm{Cu}, \mathrm{Zn}$, $\mathrm{Ni}, \mathrm{Pb}$ and $\mathrm{Cd}$ content were also reported by Kobierski (2015) in humus horizons of alluvial soils used as grasslands and arable lands in the Grudziądz Basin. Beroigui et al. (2020) also obtained higher content of above listed elements in soils of Torun city parks while $\mathrm{Cr}$ content was comparable. High content of organic carbon and iron could be also the reason of relatively high content of $\mathrm{Cu}, \mathrm{Zn}, \mathrm{Pb}, \mathrm{Ni}$ and $\mathrm{Cr}$ in $\mathrm{G} 2$ horizon of profile 3. Soil organic carbon together with Fe hydroxides are considered to have high binding capacity of these elements (Kabata-Pendias and Szteke, 2012). Another explanation is the human induced deposition of sediments as result to the possible dredging of mill pond basin. This scenario could be explained with similar content of these elements determined in the upper part of the soil profiles developed from mill pond sediments, as reported by Mendyk et al. (2016a). The results clearly demonstrate weak anthropogenic impact on the upper parts of the studied soil profiles. Moreover, the observed arrangement of values indicates the bipartite character of the studied aggerosols and supports the assumed thickness of relocated materials. Higher values were observed in the upper $80 \mathrm{~cm}$ of profile 1 , the bottom parts of profiles 2 (from $50 \mathrm{~cm}$ ) and 3 (from $100 \mathrm{~cm}$ ) formed of the material dredged from the mill pond basin during the mill's operation (profile 1) and in the mill pond's construction (profiles 2 and 3). Lower values were obtained in soil material altered in the process of terrain levelling (upper parts of profiles 2 and 3, $50 \mathrm{~cm}$ and $100 \mathrm{~cm}$, respectively).

\section{Conclusions}

According to the Polish Soil Classification (2019) the studied human-altered soils (profiles 1-3) represent aggerosols - a new soil subtype included within the technogenic soils type. Changes introduced in this matter in the newest, $6^{\text {th }}$ edition of this national soil classification system (PSC, 2019) allow for better classification of these soils in regards to their specific, human influenced genesis. The correlation of this unit with the international WRB classification system (IUSS, 2015) is convergent with the context of the most important feature, being a result of human activities leading to development of these soils (relocated soil material use of Relocatic qualifier) as proposed by Kabała et al. (2019). In the WRB system, features connected with such a human impact in the absence of high amounts of artefacts are of less importance. Thus, only the above mentioned qualifier describes the anthropogenesis of discussed pedons while recognition of other features (presence of mollic horizon or sandy texture) led us to classify these soils as Phaoezems and Arenosols in this case.

Selected metallic element contents determined in samples collected from the studied soil did not show any exceeding of the threshold values used in either national or international regula- tions. Nevertheless, the geochemical index (EF) applied for this research revealed some basic level of enrichment, especially in the case of cadmium. Higher values of determined metallic element contents and calculated index follow the morphological features indicating anthropogenic impact on the development of the studied pedons.

The obtained results could also be useful for the assessment of landscape classification, as the presented study confirms soil cover evolution at a former mill location along with changes in other elements of the geographic environment.

\section{Acknowledgments}

This research was financially supported by the Polish Ministry of Science and Higher Education subsidy for research activities of the Department of Soil Science and Land Protection of University of Life Sciences in Poznań (506.101.01.00) and cofinanced from the sources of Nicolaus Copernicus University in Toruń, grant No. 1697-G/2013.

\section{References}

Beroigui, M., Naylo, A., Walczak, M., Hafidi, M., Charzyński, P., Świtoniak, M., Różański, Sz., Boularbah, A., 2020. Physicochemical and microbial properties of urban park soils of the cities of Marrakech, Morocco and Toruń, Poland: Human health risk assessment of fecal coliforms and trace elements. CATENA 194, 104673. https://doi. org/10.1016/j.catena.2020.104673

Bishop, P., \& Muńoz-Salinas, E., 2013. Tectonics, geomorphology and water mill location in Scotland, and the potential impacts of mill dam failure. Applied Geography 42, 195-205. https://doi.org/10.1016/ j.apgeog.2013.04.010.

Brown, A.G. et al., 2016. The geomorphology of the Anthropocene: emergence, status and implications. Earth Surface Processes and Landforms 42(1), 71-90. https://doi.org/10.1002/esp.3943

Brown, A.G., Lespez, L., Sear, D.A., Macaire, J.J., Houben, P., Klimek, K., Brazier, R.E., Van Oost, K., Pears, B., 2018. Natural vs anthropogenic streams in Europe: History, ecology and implications for restoration, river-rewilding and riverine ecosystem services. Earth-Science Reviews, 180, 185-205. https://doi.org/10.1016/j.earscirev.2018.02.001

Brykała, D., Podgórski, Z., 2020. Evolution of landscapes influenced by watermills, based on examples from Northern Poland. Landscape and Urban Planning 198(2020), 103798. https://doi.org/10.1016/j.land urbplan.2020.103798

Carlon, C., D’Alessandro, M., Swartjes, F., 2007. Derivation methods of soil screening values in Europe: a review of national procedures towards harmonisation. Office for Official Publications of the European Communities EUR-OP. Scientific and Technical Research Series.

Charzyński, P., Bednarek, R., Hudańska, P., Świtoniak, M., 2018. Issues related to classification of garden soils from the urban area of Torun, Poland. Soil Science and Plant Nutrition 64(2), 132-1137. https://doi. org/10.1080/00380768.2018.1429833

Crutzen, P.J., 2006. The "Anthropocene”. [In:] Ehlers, E., Krafft, T. (Eds.), Earth system science in the Anthropocene. Springer, Berlin, Heidelberg, 13-18. https://doi.org/10.1007/3-540-26590-2_3

Egelie, G.C.M., 1977. Mills and living nature. Transactions of the 4th Symposium The International Molinological Society, TIMS, Maltock, England, 41-53.

Elias, P., Gbadegesin, A., 2011. Spatial relationships of urban land use, soils and heavy metal concentrations in Lagos Mainland Area. Journal of Applied Sciences and Environmental Management 15, 391-399. 
Fajer, M., Rzetala, M.A., 2017. Mill pond sediments as the indicator of the environment of the drainage area (an example of Liswarta River, Odra basin, Poland). Environmental Science and Pollution Research 25(6), 5832-5847. https://doi.org/10.1007/s11356-017-0909-y

Galbraith, J.M., 2018. Human-altered and human-transported (HAHT) soils in the US soil classification system. Soil Science and Plant Nutrition 64(2), 190-199. https://doi.org/10.1080/00380768.2018.1442682

Gałuszka, A., Migaszewski, Z.M., 2011. Geochemical background - an environmental perspective. Mineralogia 42(1), 7-17. https://doi. org/10.2478/v10002-011-0002-y

Howard, J.L., Daniels, W.L., 2017. Soils of Urban and Human-Impacted Landscapes. International Encyclopedia of Geography: People, the Earth, Environment and Technology 1-11. https://doi.org/10.1002/97 81118786352.wbieg0147

Hulisz, P., Michalski, A., Dąbrowski, M., Kusza, G., Łęczyński, L., 2015. Human-induced changes in the soil cover at the mouth of the Vistula River Cross-Cut (northern Poland). Soil Science Annual 66(2), 67-74. https://doi.org/10.1515/ssa-2015-0021

Hulisz, P., Charzyński, P., Greinert, A., 2018. Urban soil resources of medium-sized cities in Poland: a comparative case study of Torun and Zielona Góra. Journal of Soils and Sediments 18, 358-372. https://doi. org/10.1007/s11368-016-1596-x

Hupp, C.R., Noe, G.B., Schenk, E.R., Benthem, A.J., 2013. Recent and historic sediment dynamics along Difficult Run, a suburban Virginia Piedmont stream. Geomorphology 180-181(1), 156-169. https://doi. org/10.1016/j.geomorph.2012.10.007

IUSS Working Group WRB, 2015. World Reference Base for soil resources 2014. International soil classification system for naming soils and creating legends for soil maps. Update 2015. World Soil Resources Report No. 106. FAO, Rome

Jahn, R., Blume, H.P., Asio, V.B., Spaargaren, O., Schad, P., 2006. Guidelines for soil description. FAO.

Jankowski, M., Bednarek, R., Jaworska, M., 2013. Soils constructed on the 19th century fortifications in Toruń. [In:] Charzyński, P., Hulisz, P., Bednarek, R., (Eds.), Technogenic soils of Poland. Polish Society of Soil Science, Toruń.

Jonczak, J., Florek, W., 2013. Wiek i właściwości gleb wykształconych z osadów stawu młyńskiego w dolinie Jarosławianki (Równina Sławieńska). [In:] (Jonczak J., Florek W., Eds.) Środowisko glebotwórcze i gleby dolin rzecznych. Bogucki Wydawnictwo Naukowe, PoznańSłupsk, 33-40.

Jonczak, J., 2015. Buffering properties of the soils developed from millpond deposits in the valley of the Jarosławianka Creek. Baltic Coastal Zone. Journal of Ecology and Protection of the Coastline 19, 37-48.

Kabała, C. et al., 2019. Polish Soil Classification, 6th edition - principles, classification scheme and correlations. Soil Science Annual 70(2), 71-97. https://doi.org/10.2478/ ssa-2019-0009

Kabata-Pendias, A., Szteke B., 2012. Pierwiastki śladowe w geo- i biosferze. Instytut Uprawy, Nawożenia i Gleboznawstwa. Państwowy Instytut Badawczy. Puławy.

Kaiser, K. et al., 2018. A large-scale medieval dam-lake cascade in central Europe: Water level dynamics of the Havel River, Berlin-Brandenburg region, Germany. Geoarchaeology 33(2), 237-259. https://doi. org/10.1002/gea.21649.

Kaiser, K. et al., 2020. Palaeosols and their cover sediments of a glacial landscape in northern central Europe: Spatial distribution, pedostratigraphy and evidence on landscape evolution. Catena 193, 104647. https://doi.org/10.1016/j.catena.2020.104647

Kittel, P. et al., 2014. A multi-proxy reconstruction from Lutomiersk-Koziówki, Central Poland, in the context of early modern hemp and flax processing. Journal of Archaeological Science 50, 318-337. https://doi.org/10.1016/j.jas.2014.07.008

Kobierski, 2015. Evaluation of the content of heavy metals in fluvisols of floodplain area depending on the type of land use. Journal of Ecological Engineering 16(1), 23-31.
Kot R., 2018. Mezoregiony fizycznogeograficzne (2018) 1:1000000. Internetowy Atlas Województwa Kujawsko-Pomorskiego. http://atlas.kujawsko-pomorskie.pl/maps/app/map\# [10 August 2020].

Kottek, M., Grieser, J., Beck, C., Rudolf, B., Rubel, F., 2006. World Map of the Köppen-Geiger climate classification updated. Meteorologische Zeitschrift 15(3), 259-263. https://doi.org/10.1127/0941-2948/2006/0130

Kowalska, J., Mazurek, R., Gąsiorek, M., Zaleski, T., 2018. Pollution indices as useful tools for the comprehensive evaluation of the degree of soil contamination - A review. Environmental Geochemistry and Health 40, 2395-2420. https://doi.org/10.1007/s10653-018-0106-z.

Krupski, M., Kabala, C., Sady, A., Gliński, R., Wojcieszak, J., 2017. Double- and triple-depth digging and Anthrosol formation in a medieval and modern-era city (Wrocław, SW Poland). Geoarchaeological research on past horticultural practices. Catena 153, 9-20. https://doi. org/10.1016/j.catena.2017.01.028

Laurance, W.F., 2019. The Anthropocene. Current Biology, 29 (19), R953R954. https://doi.org/10.1016/j.cub.2019.07.055

Łabaz, B., Kabala, C., 2016. Human-induced development of mollic and umbric horizons in drained and farmed swampy alluvial soils. Catena 139, 117-126. https://doi.org/10.1016/j.catena.2015.12.013

Madry, S., Jones, E.A., Tickner, A., Murray, S., Misner, T., 2015. Water and landscape dynamics in southern Burgundy: Two and a half centuries of water management in an agricultural landscape. Water History 7(3), 301-335. https://doi.org/10.1007/ s12685-015-0132-z.

Matuszkiewicz, J.M., 2008. Potential natural vegetation of Poland (Potencjalna roślinność naturalna Polski), Map sheet B2. IGiPZ PAN, Warszawa. https://www.igipz.pan.pl/tl_files/igipz/ZGiK/opracowania/roslinnosc_potencjalna/B2.png

Matschullat, J., Ottenstein, R., \& Reimann, C., 2000. Geochemical background - Can we calculate it? Environmental Geology 39, 990-1000. https://doi.org/10.1007/s002549900084

Marcinek, J., Spychalski, M., 1987. Wpływ zawartości materii organicznej na fizyczne właściwości gleb hydromorficznych. Roczniki Akademii Rolniczej w Poznaniu. Melioracje 7, 19-33.

Mendyk, Ł., Świtoniak, M., Bednarek, R., Falkowski, A., 2015. Genesis and classification of the soils developed from the sediments of the former Oleszek mill pond basin (the Chełmińskie Lakeland, N Poland)/ Geneza i pozycja systematyczna gleb wykształconych z osadów niecki dawnego stawu młyńskiego Oleszek (Pojezierze Chełmińskie). Soil Science Annual 66(1), 29-35. https://doi.org/10.1515/ssa-20150016

Mendyk, Ł., Hulisz, P., Kusza, G., Świtoniak, M., Gersztyn, L., Kalisz, B., 2016a. Sediment origin and pedogenesis in the former mill pond basin of Turznice (north-central Poland) based on magnetic susceptibility measurements. Bulletin of Geography. Physical Geography Series 11(1), 55-69. https://doi.org/10.1515/bgeo-2016-0015

Mendyk, Ł., Markiewicz, M., Bednarek, R., Świtoniak, M., Gamrat, W.W., Krześlak, I., Sykuła, M., Gersztyn L., Kupniewska, A., 2016b. Environmental changes of a shallow kettle lake catchment in a young glacial landscape (Sumowskie Lake catchment), North-Central Poland. Quaternary International 418, 116-131. https://doi.org/10.1016/ j.quaint.2015.10.008

Ministry of the Environment, Finland, 2007. Government Decree on the Assessment of Soil Contamination and Remediation Needs. 214/2007 (March 1, 2007). https://www.finlex.fi/en/laki/kaannokset/2007/ en20070214.pdf

Pardela, Ł., Kowalczyk, T., Bogacz, A., Kasowska, D., 2020. Sustainable Green Roof Ecosystems: 100 Years of Functioning on Fortifications - A Case Study. Sustainability 12(11), 4721. https://doi.org/10.3390/ su12114721

Podgórski, Z., 2004. Wpływ budowy i funkcjonowania młynów wodnych na rzeźbę terenu i wody powierzchniowe Pojezierza Chełmińskiego i przyległych części dolin Wisły i Drwęcy. Wyd. Nauk. UMK, Toruń.

Polish Soil Classification, 2019. Polskie Towarzystwo Gleboznawcze, Komisja Genezy Klasyfikacji i Kartografii Gleb. Wydawnictwo Uniwer- 
sytetu Przyrodniczego we Wrocławiu, Polskie Towarzystwo Gleboznawcze, Wrocław - Warszawa.

Regulation ME, 2016. Regulation of the Minister of the Environment of September 1, 2016 on how to assess the pollution of the land surface. http://prawo.sejm.gov.pl/isap.nsf/DocDetails.xsp?id=WDU2016000 1395

Ripin, S.N.M., Hasan, S., Kamal, M.L., Hashim, N.M., 2014. Analysis and pollution assessment of heavy metal in soil, Perlis. The Malaysian Journal of Analytical Sciences 18, 155-161.

Royall, D., Kennedy, L., 2016. Historical erosion and sedimentation in two small watersheds of the southern Blue Ridge Mountains, North Carolina, USA. Catena 143, 174-186. https://doi.org/10.1016/ j.catena.2016.03.020

Soil Survey Division Staff, 1993. Soil Survey Manual. Soil Conservation Service. U.S. Department of Agriculture Handbook, 18.

Sutherland, R.A., 2000. Bed sediment-associated trace metals in an urban stream, Oahu, Hawaii. Environmental Geology 39, 611-627. https:// doi.org/10.1007/s002540050473

Świtoniak, M., 2014. Use of soil profile truncation to estimate influence of accelerated erosion on soil cover transformation in young morainic landscapes, North-Eastern Poland. Catena 116, 173-184. https://doi. org/10.1016/j.catena.2013.12.015
Świtoniak, M., 2015. Issues relating to classification of colluvial soils in young morainic areas (Chełmno and Brodnica Lake District, northern Poland). Soil Science Annual 66(2), 57-66. https://doi.org/10.1515/ ssa-2015-0020

Tóth, G., Hermann, T., Szatmári, G., Pásztor, L., 2016. Maps of heavy metals in the soils of the European Union and proposed priority areas for detailed assessment. Science of the total environment 565, 10541062. https://doi.org/10.1016/j.scitotenv.2016.05.115

UNEP, 2013. Environmental Risks and Challenges of Anthropogenic Metals Flows and Cycles. [In:] van der Voet, E., Salminen, R., Eckelman, M., Mudd, G., Norgate, T., Hischier, R. (Eds.), A Report of the Working Group on the Global Metal Flows to the International Resource Panel.

Waters, C.N. et al., 2016. The Anthropocene is functionally and stratigraphically distinct from the Holocene. Science, 351, 6269. https://doi. org/10.1126/science.aad2622

Wójcik, G., Marciniak, K., 1987. Thermal conditions in central part of the North Poland in the years 1951-1970. Acta Universitatis Nicolai Copernici Geografia 20, 29-50 (in Polish).

Wójcik, G., Marciniak, K., 1993. Precipitations in Lower Vistula Valley in the years 1951-1980. [In:] Churski, Z. (Ed.), Environmental and Socioeconomic Development of the Lower Vistula Valley. IG UMK, Toruń, 107-121. 